\title{
Dimethyl fumarate treatment of relapsing-remitting multiple sclerosis influences B-cell subsets
}

\section{OPEN}

Steven K. Lundy, PhD

Qi Wu, PhD

Qin Wang, PhD

Catherine A. Dowling, MD

Sophina H. Taitano, BS Guangmei Mao, PhD

Yang Mao-Draayer, MD, $\mathrm{PhD}$

Correspondence to Dr. Mao-Draayer: maodraay@umich.edu

\section{ABSTRACT}

Objective: To test the hypothesis that dimethyl fumarate (Tecfidera, BG-12) affects B-cell subsets in patients with relapsing-remitting multiple sclerosis (RRMS).

Methods: Peripheral blood B cells were compared for surface marker expression in patients with RRMS prior to initiation of treatment, after 4-6 months, and at more than 1 year of treatment with BG-12. Production of interleukin (IL)-10 by RRMS patient B cells was also analyzed.

Results: Total numbers of peripheral blood B lymphocytes declined after 4-6 months of BG-12 treatment, due to losses in both the CD27+ memory B cells and CD27 neg B-cell subsets. Some interpatient variability was observed. In contrast, circulating CD24 ${ }^{\text {high }} \mathrm{CD} 38^{\text {high }}$ (T2-MZP) B cells increased in percentage in the majority of patients with RRMS after 4-6 months and were present in higher numbers in all of the patients after 12 months of treatment. The $\mathrm{CD} 43+\mathrm{CD} 27+\mathrm{B}-1 \mathrm{~B}$ cells also increased at the later time point in most patients but were unchanged at 4-6 months compared to pretreatment levels. Purified B cells from 7 of the 9 patients with RRMS tested after 4-6 months of treatment were able to produce IL-10 following CD40 ligand stimulation, and the amount corresponded with the combined levels of T2-MZP and B-1 B cells in the sample. None of the patients with RRMS in this study have had a relapse while taking BG-12.

Conclusions: These data suggest that BG-12 differentially affects B-cell subsets in patients with RRMS, resulting in increased numbers of circulating B lymphocytes with regulatory capacity.

Neurol Neuroimmunol Neuroinflamm 2016;3:e211; doi: 10.1212/NXI.0000000000000211

\section{GLOSSARY}

CBC = complete blood count; DMF = dimethyl fumarate; EAE = experimental autoimmune encephalomyelitis; HO-1 = heme oxygenase-1; IL-10 = interleukin-10; MS = multiple sclerosis; Nrf2 = nuclear factor (erythroid-derived 2)-like 2; PBL = peripheral blood lymphocytes; PBMC = peripheral blood mononuclear cells; PML = progressive multifocal leukoencephalopathy; RRMS = relapsing-remitting multiple sclerosis; T2-MZP = transitional 2 marginal zone precursor.

Treatment of relapsing-remitting multiple sclerosis (RRMS) has advanced with the approval of new medications. ${ }^{1,2}$ BG-12 (Tecfidera; Biogen Idec, Cambridge, MA), an oral formulation of dimethyl fumarate (DMF), lowered relapse rates in clinical trials. ${ }^{3,4}$ Neuroprotective effects and ease of administration of BG-12 has led to increased use as a front-line treatment for RRMS. ${ }^{5-7}$ Recently reported cases of progressive multifocal leukoencephalopathy (PML) in DMF-treated patients with RRMS have raised concerns about the long-term safety of BG-12. ${ }^{8-10}$ In recent studies, BG-12 treatment led to decreases in CD4+ and CD8 + T cells and B cells. ${ }^{11,12}$ The mechanisms underlying these effects in RRMS are unknown; however, fumarates have induced lymphocyte apoptosis and elevated production of the immune suppressive cytokine interleukin10 (IL-10). ${ }^{13-15}$ Major producers of IL-10 include regulatory CD4 + T lymphocytes (Treg) and B lymphocytes (Breg), which have moderated CNS inflammation in the experimental

From the Department of Internal Medicine, Division of Rheumatology (S.K.L.), Graduate Program in Immunology, Program in Biomedical Sciences (S.K.L., S.H.T., Y.M.-D.), and Department of Neurology (Q. Wu, Q. Wang, C.A.D., G.M., Y.M.-D.), University of Michigan Medical School, Ann Arbor.

Funding information and disclosures are provided at the end of the article. Go to Neurology.org/nn for full disclosure forms. The Article Processing Charge was paid by authors.

This is an open access article distributed under the terms of the Creative Commons Attribution-NonCommercial-NoDerivatives License 4.0 (CC BY-NC-ND), which permits downloading and sharing the work provided it is properly cited. The work cannot be changed in any way or used commercially. 
autoimmune encephalomyelitis (EAE) mouse model. ${ }^{16,17}$ The effects of BG-12 treatment specifically on IL-10-producing lymphocytes have not been previously reported in patients with RRMS.

This prospective cohort study focused on testing the hypothesis that BG-12 treatment alters B-cell subtypes in patients with RRMS. Peripheral blood was collected from controls and patients with RRMS before and after treatment with oral BG-12. Total B-cell levels were reduced after treatment, with decreased levels of memory, immature, and naive B cells. In contrast, significant increases in the total numbers of $\mathrm{CD} 24^{\text {high }} \mathrm{CD} 38^{\text {high }} \mathrm{B}$ cells and $\mathrm{CD} 27+\mathrm{CD} 43+\mathrm{B}$ cells were observed. These data demonstrate a novel way in which BG-12 may exert therapeutic effects in patients with RRMS.

METHODS Standard protocol approvals, registrations, and patient consents. Patients with a diagnosis of RRMS who had been prescribed BG-12 were enrolled in this prospective cohort study. Informed consent was obtained from all patients and controls prior to participation in the protocol, which was approved by the University of Michigan Institutional Review Board.

Demographics and blood samples. Patients were between 18 and 65 years of age, had not received another nonsteroidal disease-modifying therapy within the last 30 days, and had not had IV immunoglobulin therapy or plasmapheresis in the last 6 months. Four of 5 patients who had received oral or injected steroid treatments discontinued use more than 1 month before taking BG-12, and the other patient began a 6 -week taper at the time of starting BG-12. Table 1 lists previous nonsteroidal medications taken by each patient and the time of discontinuation. Patients were put on a dose escalation schedule and all reached 240 mg BG-12 twice daily within 1-5 weeks of treatment initiation. A total of 13 patients with RRMS were followed longitudinally from pretreatment to 4-6 months of treatment with BG-12. A baseline peripheral blood sample was drawn within 2 months prior to initiation of BG-12, and after 46 months $(20.5 \pm 3.8$ weeks $)$ of reaching the standard dose of BG-12. Sex and age of the patients was 8/13 (61.5\%) female, average age $46.0 \pm 8.7$ years (median 46.5 ; range $31-58$ ). The 5 men were $40.4 \pm 9.8$ years old (median 35 ; range 33-57). Eight of these patients had a follow-up sample taken after 12 months of treatment (see table 1). Peripheral blood mononuclear cells (PBMC) were also obtained from 6 healthy controls: $4 / 6$ (66.7\%) female, average age $48.0 \pm 9.1$ years (median 47.0; range 38-60), and 2 men aged 31 and 49 years. Two female patients with RRMS and one female control were of African American descent. All other participants were non-Hispanic Caucasian. Blood samples $(20-25 \mathrm{~mL})$ from all participants were collected in sodium citrate cell preparation tubes and processed immediately. Complete blood counts (CBCs) were obtained from the clinical pathology laboratory. Total B-cell numbers were calculated by multiplying percentages from flow cytometry and CBC lymphocyte counts.
Flow cytometry. Isolated PBMC from patients and controls were stained with monoclonal antibodies reactive against the cell surface markers CD19, CD27, and CD43 purchased from BD Biosciences (East Rutherford, NJ) and CD24 and CD38 from BioLegend (San Diego, CA). Multicolor flow cytometry was performed for all samples on a Beckman Coulter (Sharon Hill, PA) LSR flow cytometer using standardized voltage and compensation settings. Gating was determined using healthy control samples and was consistent throughout the study. Data analysis was performed using Tree Star (Ashland, OR) FlowJo version X.0.6 software.

Human B-cell culture and IL-10 analysis. Purified B cells were isolated from PBMC by magnetic bead separation using anti-human CD19 magnetic-activated cell sorting beads and the protocol provided by Miltenyi Biotec (Bergisch Gladbach, Germany). Labeled cells were positively selected over LS columns (Miltenyi Biotec) and were routinely $>98 \%$ pure. B cells were cultured in high glucose Dulbecco Modified Eagle Medium supplemented with $10 \%$ heat-inactivated fetal calf serum, penicillin, streptomycin, insulin $(5 \mu \mathrm{g} / \mathrm{mL})$, and transferrin $(50 \mu \mathrm{g} / \mathrm{mL})$ with irradiated human CD40 ligandtransduced fibroblasts for 6 days. Cell-free supernatants were removed and analyzed for the presence of human IL-10 using OptEIA kit (BD Biosciences) following the manufacturer's protocol. Concentrations of IL-10 were determined in comparison to standard curves.

Data collection and statistical analysis. Flow cytometric data were obtained from $>20,000$ lymphocytes from each sample. Statistics were performed using GraphPad (La Jolla, CA) Prism 6.01. Medians and interquartile ranges for each group were determined. Exact $p$ values were calculated using the appropriate statistical tests for each dataset as indicated in the figure legends. Two-way analysis of variance with Dunn multiple comparison tests were used to establish statistical significance for datasets containing 3 or more groups. Comparisons of control and patient samples were performed using Mann-Whitney tests. Paired comparisons of time point data for individual patients were done using Wilcoxon matched-pairs signed-rank tests.

\section{RESULTS BG-12 treatment reduced circulating memory} and naive $B$ cells. Treatment of RRMS with the Food and Drug Administration-approved oral drug, BG12 (Tecfidera), is known to reduce total PBMC counts compared to pretreatment levels. ${ }^{3,18}$ Decreases involve both the $\mathrm{T}$ - and the B-lymphocyte populations, yet detailed analysis within these major lymphocyte lineages has not been reported. ${ }^{11,12} \mathrm{~B}$ cells can be subdivided into groups with distinct functions and states of activation that are distinguishable based on surface marker expression patterns. ${ }^{19}$ In this prospective cohort study, B-cell subsets were analyzed from 13 patients with RRMS (table 1) before and after 4-6 months of treatment with $240 \mathrm{mg}$ twice daily oral BG-12. Eight patients were also tested after more than 1 year. Table 1 outlines the demographics and other clinical data for each patient including previous treatments and CBC lymphocyte counts. Patients 3, 4,10 , and 11 had taken oral or injected corticosteroids that were discontinued prior to starting BG-12 therapy. Patient 1 had a flare that was treated with 


\begin{tabular}{|c|c|c|c|c|c|c|c|c|c|c|c|c|c|}
\hline \multirow[t]{3}{*}{ Table 1} & \multicolumn{13}{|c|}{ Patient demographics and clinical information } \\
\hline & \multirow[b]{2}{*}{ Sex } & \multirow[b]{2}{*}{$\begin{array}{l}\text { Age at } \\
\text { baseline, y }\end{array}$} & \multirow[b]{2}{*}{ Ethnicity } & \multicolumn{2}{|l|}{ Pretreatment } & \multicolumn{2}{|c|}{ 4-6 Months sample } & \multicolumn{2}{|c|}{$>12$ Months sample } & \multirow[b]{2}{*}{$\begin{array}{l}\text { Prior NS } \\
\text { DMT }\end{array}$} & \multirow[b]{2}{*}{$\begin{array}{l}\text { Time since } \\
\text { previous DMT }\end{array}$} & \multirow[b]{2}{*}{$\begin{array}{l}\text { Relapses after } \\
\text { BG-12 started }\end{array}$} & \multirow[b]{2}{*}{$\begin{array}{l}\text { Time since last } \\
\text { relapse (prebaseline) }\end{array}$} \\
\hline & & & & $\begin{array}{l}\text { Months } \\
\text { before BG-12 }\end{array}$ & $\begin{array}{l}\text { CBC lymph } \\
\text { (millions) }\end{array}$ & $\begin{array}{l}\text { Months from } \\
\text { BG-12 start }\end{array}$ & $\begin{array}{l}\text { CBC lymph } \\
\text { (millions) }\end{array}$ & $\begin{array}{l}\text { Months from } \\
\text { BG-12 start }\end{array}$ & $\begin{array}{l}\text { CBC lymph } \\
\text { (millions) }\end{array}$ & & & & \\
\hline RRMS-1 & $\mathrm{F}$ & 53 & c & -0.75 & 1.8 & 5 & ND & 26 & 0.8 & None & & None & $0 \mathrm{mo}^{\mathrm{a}}$ \\
\hline RRMS-2 & M & 33 & c & -2 & 4.0 & 4 & 1.1 & 15 & 1.6 & Enbrel $^{\mathrm{b}}$ & $16 \mathrm{mo}$ & None & $8 \mathrm{mo}$ \\
\hline RRMS-3 & M & 56 & c & -0.25 & 2.8 & 5 & 2.2 & 25 & 0.8 & None & & None & $0.5 \mathrm{mo}$ \\
\hline RRMS-4 & $\mathrm{F}$ & 37 & C & -0.75 & 0.8 & 4 & 0.6 & 23 & 0.8 & None & & None & $2 \mathrm{mo}$ \\
\hline RRMS-5 & $\mathrm{F}$ & 46 & C & -2 & 2.0 & 4 & 1.2 & 20 & 1.5 & Avonex & $12 \mathrm{mo}$ & None & Unknown \\
\hline RRMS-6 & $\mathrm{F}$ & 51 & AA & -1 & 2.7 & 4 & 1.4 & ND & ND & Copaxone & $13 \mathrm{mo}$ & None & Unknown \\
\hline RRMS-7 & M & 35 & c & 0 & 2.3 & 4 & 1.5 & 20 & 1.6 & Rebif & $1 \mathrm{mo}^{\mathrm{c}}$ & None & $12 y$ \\
\hline RRMS-8 & $\mathrm{F}$ & 31 & AA & -0.5 & 3.1 & 4 & 2.7 & ND & ND & Avonex & $1 \mathrm{mo}$ & None & $2 y$ \\
\hline RRMS-9 & $\mathrm{F}$ & 45 & c & $-5^{d}$ & 1.5 & 4 & 0.8 & ND & ND & Rebif & $2 y$ & None & $6 \mathrm{mo}$ \\
\hline RRMS-10 & $\mathrm{F}$ & 47 & C & -0.5 & 1.5 & 6 & 0.7 & 16 & 0.6 & None & & None & $4 \mathrm{mo}$ \\
\hline RRMS-11 & $\mathrm{F}$ & 58 & C & -0.5 & 1.6 & 4 & 1.9 & 13 & 1.7 & None & & None & $9 \mathrm{mo}$ \\
\hline RRMS-12 & M & 34 & C & 0 & 2.8 & 6 & 1.6 & ND & ND & None & & None & $2 \mathrm{mo}$ \\
\hline RRMS-13 & $M$ & 44 & C & -0.25 & 2.9 & 5 & 1.5 & ND & ND & Avonex & $3 \mathrm{mo}$ & None & $3 \mathrm{mo}$ \\
\hline
\end{tabular}

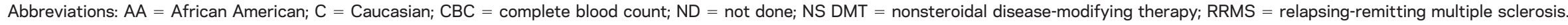
a Patient relapsed 1 week after baseline and took steroids until starting BG-12, then tapered off steroids over 6 weeks.

${ }^{b}$ Enbrel was taken for ankylosing spondylitis and discontinued 16 months prior to baseline pretreatment sample.

${ }^{\mathrm{C}}$ Rebif taken intermittently for 12 years, discontinued 1 month prior to baseline sample.

${ }^{\mathrm{d}}$ Patient started BG-12 briefly at 0 months from pretreatment blood sample, then restarted 5 months later. Timing of other samples adjusted to restart date. 
oral corticosteroids just prior to entering the study, and was tapered off of steroids immediately after BG-12 treatment was initiated.

Most (11 of 12) of the patients had a marked reduction in peripheral blood lymphocytes (PBL) after 4-6 months treatment with BG-12 compared to pretreatment levels (table 1). Levels of PBL did not decrease between the 4 and 6 months and $>1$ year time points for most patients. To determine the effects of BG-12 on B cells, flow cytometric analysis was performed on longitudinal samples from the patients with RRMS. Six healthy individuals who had similar demographics for age, sex, and ethnicity were used as controls. Figure $1 \mathrm{~A}$ shows the gating used select CD19+ B cells from a representative patient (RRMS 8) at baseline and 4 months after starting
BG-12. The majority of these patients with RRMS had an elevated percentage of CD19+ B cells prior to BG-12 treatment compared to controls (figure 1B). A significant decrease in the total number of B cells was observed at 4-6 months of treatment compared to pretreatment levels (figure 1C and table 2). The total number of circulating CD19+ B cells in the patients with RRMS did not significantly decrease between 4 and 6 months of treatment and more than 1 year of treatment (table 2).

Decreased circulating memory and naive $B$ cells in BG-12-treated patients with RRMS. CD27 has been commonly used to distinguish activated/memory B cells from other B-cell subsets or activation states. ${ }^{19}$ $\mathrm{CD} 19+\mathrm{CD} 27+$ cells were analyzed before and after

Figure 1 BG-12 treatment reduced total circulating B cells and had variable effects on memory B cells

A
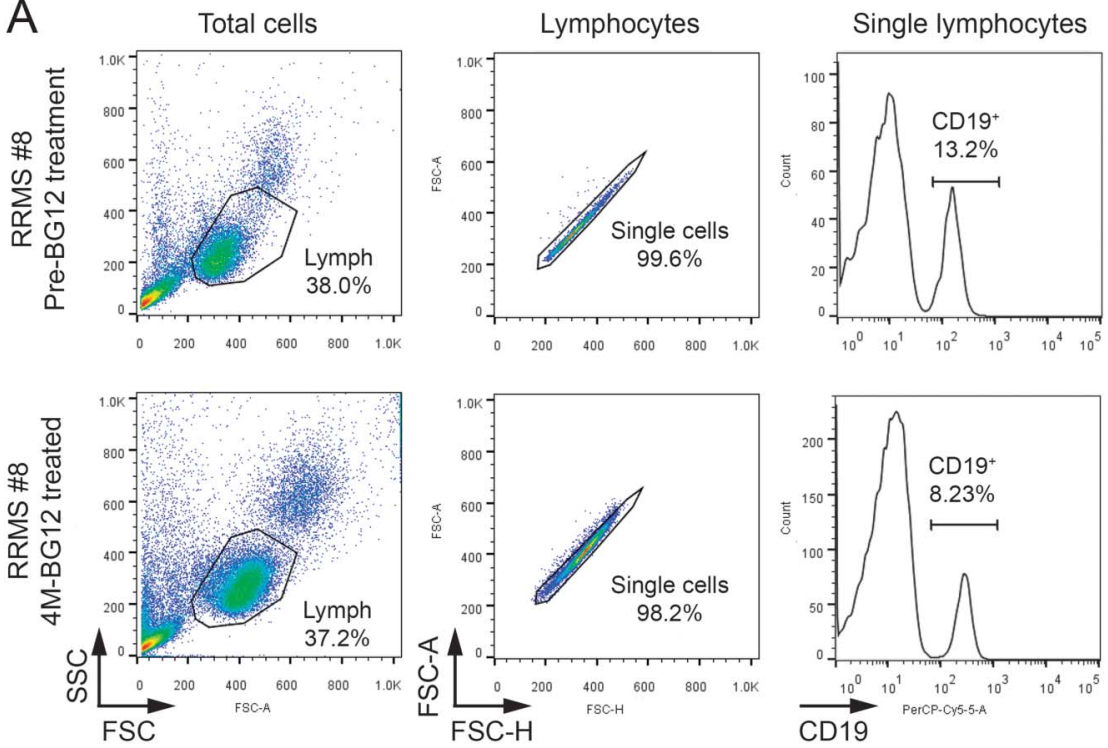

$\mathrm{D}$
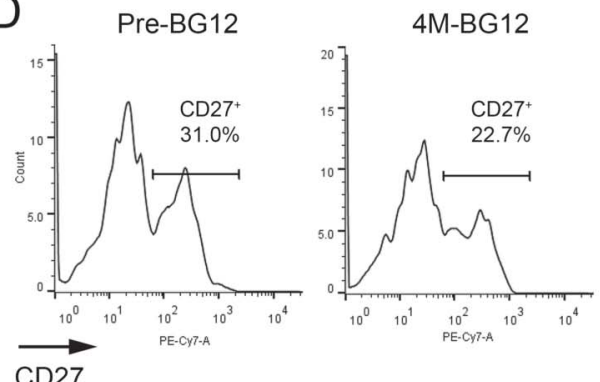

E

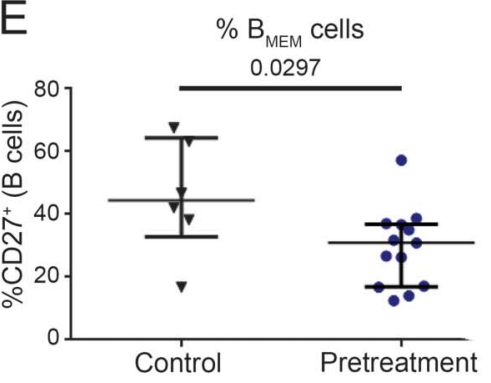

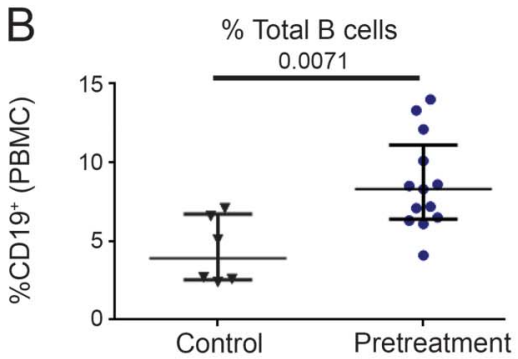

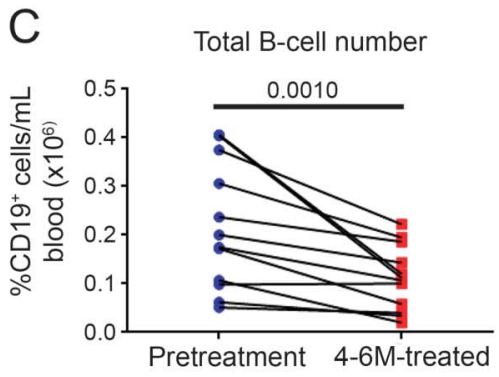

$\mathrm{F} \quad \% \mathrm{~B}_{\text {MEM }}$ cells

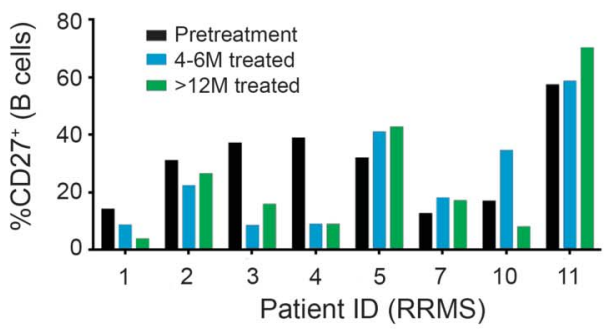

Peripheral blood mononuclear cells (PBMC) isolated from patients with relapsing-remitting multiple sclerosis (RRMS) before and after BG-12 treatment and healthy controls were stained for B-cell markers. (A) Representative forward scatter, side scatter, and anti-CD19 staining from a single patient (RRMS-8) shows standardized gating for lymphocytes, single cells, and total CD19+ B cells that was used for all of the samples. (B) Comparison of \%CD19+ B cells for healthy controls and patients with RRMS before treatment. Each dot represents an individual sample and lines are the median interquartile range for each group. The exact $p$ value shown below the title was calculated using Mann-Whitney test. (C) Total B-cell numbers $/ \mathrm{mL}$ of blood for the patients with RRMS were calculated before and after 4-6 months of treatment by multiplying the \%CD19+ cells by the lymphocyte counts reported by the clinical pathology laboratory (table 1). Lines connect individual patients. Exact $p$ value for paired patient data was determined using Wilcoxon matched-pairs signed-rank test. (D) Representative histograms from patient RRMS-8 show gating used to define CD27+ memory B cells. (E) Percentages of CD27+ memory B cells in patients with RRMS before treatment compared with controls. Each dot represents data from one individual and lines are the median and interquartile range for each group. The $p$ value was calculated using Mann-Whitney test. $(F)$ Longitudinal \%CD27+ memory B-cell data for individual patients with RRMS ( $n=8$ ) before, after 4-6 months, and after more than 1 year of treatment with BG-12. 


\begin{tabular}{|c|c|c|c|c|c|}
\hline \multirow[t]{2}{*}{ otal cell numbe } & peripheral blood B-c & subsets & & & \\
\hline & $\begin{array}{l}\text { A: Pretreatment, } \\
\text { cells } / \mathrm{mL}(\mathrm{n}=13)\end{array}$ & $\begin{array}{l}\text { B: } 4-6 \text { months BG-12, } \\
\text { cells } / \mathrm{mL}\left(n=12^{\mathrm{a}}\right)\end{array}$ & $p$ Value, A vs B & $\begin{array}{l}\text { C: }>12 \text { months BG-12, } \\
\text { cells } / \mathrm{mL}\left(\mathrm{n}=8^{\mathrm{a}}\right)\end{array}$ & p Value, A vs C \\
\hline \multicolumn{6}{|l|}{ Major B-cell subsets } \\
\hline Total CD19+ & $211,000 \pm 35,000$ & $111,000 \pm 19,000$ & $0.001^{b}$ & $95,000 \pm 26,000$ & 0.148 \\
\hline Total CD27+ & $57,000 \pm 9,000$ & $27,000 \pm 6,000$ & $0.002^{b}$ & $23,000 \pm 9,000$ & 0.078 \\
\hline \multicolumn{6}{|l|}{ Regulatory B-cell subsets } \\
\hline CD24 ${ }^{\text {high }} C D 38^{\text {high }}$ & $5,600 \pm 1,400$ & $9,400 \pm 3,000$ & 0.470 & $12,000 \pm 2,600$ & $0.008^{b}$ \\
\hline CD43+CD27+ (no RRMS-3') & $4,200 \pm 3,700$ & $2,900 \pm 600$ & 0.413 & $8,200 \pm 2,000$ & $0.016^{b}$ \\
\hline
\end{tabular}

Abbreviations: $\mathrm{CBC}=$ complete blood count; RRMS = relapsing-remitting multiple sclerosis.

Mean cell counts \pm standard error based on $\mathrm{CBC}$ total lymphocyte number multiplied by \% of the indicated B-cell subset.

${ }^{a}$ Number of individuals varied based on sampling and available CBC lymphocyte counts (no 4-6 month CBC for RRMS-1).

${ }^{\mathrm{b}}$ The $p$ values for matched pairs were calculated using Wilcoxon tests; $p<0.02$ was considered significant.

${ }^{\mathrm{c}}$ Baseline CD43+CD27+ for RRMS-3 was 12 SD away from the mean of other samples and was removed as outlier for all time points.

treatment with BG-12 (figure 1, D-F). Patients with RRMS in this study had lower percentages of circulating CD27+ memory B cells prior to BG-12 treatment than the controls (figure 1E), suggesting that the $\mathrm{CD} 27^{\text {neg }} \mathrm{B}$ cells, which include a mixture of immature, transitional, and naive B-cell subsets, were overrepresented in the patients with RRMS before treatment. As shown in figure $1 \mathrm{~F}$, there was some variability in the relative levels of memory vs naive $\mathrm{B}$ cells in the patients with RRMS before treatment, and BG-12 had differential effects on the ratios. Treatment for 4-6 months led to decreases in the absolute number of circulating CD27+ B cells in all but one patient. The exception was patient RRMS-10, who went on to have fewer memory B cells after 1 year of treatment than at baseline (data not shown). Long-term treatment with BG-12 did not lead to further significant reductions in the total number of $\mathrm{CD} 27+\mathrm{B}$ cells in most patients (table 2) or a consistent change in the ratio of $\mathrm{CD} 27+$ to $\mathrm{CD} 27^{\text {neg }} \mathrm{B}$ cells (figure $2 \mathrm{C}$ ). Taken together, these results suggest that BG-12 treatment did not have a selective effect on either the CD27+ memory B cells or the $\mathrm{CD} 27^{\text {neg }}$ immature, transitional, or naive $\mathrm{B}$ cells, but that there was a generalized decrease of both B-lymphocyte populations in patients with RRMS.

Increased $\mathrm{CD} 24^{\text {high }}{ }^{\mathrm{CD}} 38^{\text {high }}$ and $\mathrm{CD} 43+\mathrm{CD} 27+\mathrm{B}$ cells after BG-12 treatment. The $\mathrm{CD} 27^{\text {neg }}$ and $\mathrm{CD} 27+$ B-cell populations can be further subdivided into functionally distinct subsets. Notably, a subset of regulatory B cells that produce IL-10 has been found within the $\mathrm{CD} 27^{\text {neg }}$ and $\mathrm{CD} 27+\mathrm{B}$-cell subsets. $\mathrm{CD} 27^{\text {neg }} \mathrm{B}$ cells that are $\mathrm{CD} 24^{\text {high }} \mathrm{CD} 38^{\text {high }}$ (figure 2A) have been previously classified as transitional 2 marginal zone precursor (T2-MZP) B cells that produce IL-10.20,21 Circulating T2-MZP B cells were reduced in percentage in these patients with
RRMS prior to treatment in comparison to controls (figure 2B). Unlike the total CD27 ${ }^{\text {neg }} \mathrm{B}$-cell subset, increases in T2-MZP B cells were detected in 10 of 13 patients at 4-6 months treatment, and were higher than baseline in all 8 patients who were followed for more than 1 year (figure 2C). Despite reductions in total $\mathrm{B}$ cells, the number of circulating T2-MZP B cells tended to be higher after 4-6 months of BG-12 treatment and continued to increase over the longer term, resulting in significantly higher total T2-MZP B-cell numbers in the circulation of patients with RRMS after 1 year of BG-12 treatment (table 2).

The CD27+CD43+ B-cell subset (figure 2D) has been identified as an innate-like B-1 B-cell subtype that, similar to its counterpart in mice, has the capacity to produce IL-10 and to regulate immune responses. $^{22,23}$ Prior to treatment, B-1 B cells were found in the circulation at very low levels in all but one of the 13 patients with RRMS in our study in comparison to healthy controls (figure 2E). Despite the inclusion of patient RRMS-3, whose B-1 cells were within the normal range, the patients averaged a more than fourfold lower percentage of B-1 B cells than controls. The B-1 B cells responded somewhat differently to BG-12 treatment compared to T2MZP B cells (figure 2F). After 4-6 months of treatment with BG-12, the percentage of circulating B-1 $\mathrm{B}$ cells was not significantly changed (figure $2 \mathrm{~F}$ ), and there was variability in the response from patient to patient. However, after 1 year of treatment, 6 of 8 patients with RRMS had a substantially higher percentage of B-1 B cells than what was present prior to BG-12 treatment. With the exception of patient RRMS-3, who had 48,800 B-1 B cells/mL of blood at baseline compared to the $4,200 \pm 3,700 \mathrm{~B}-1 \mathrm{~B}$ cells $/ \mathrm{mL}$ average for the other 7 patients, there was a significant increase in the total number of circulating B-1 B cells after long-term treatment with BG-12 (table 2). 
Figure 2 Increases in CD24 $4^{\text {high } C D 38^{\text {high }}}$ transitional 2 marginal zone precursor (T2-MZP) and CD27+CD43+ B-1 B cells after BG-12 treatment

A

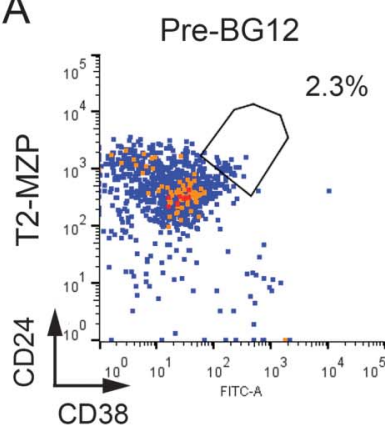

$4 \mathrm{M}-\mathrm{BG} 12$

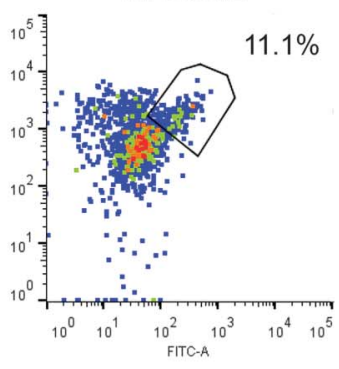

B

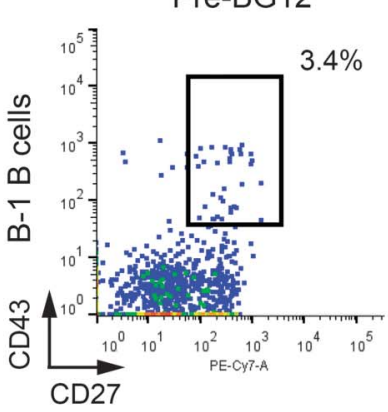

4M-BG12

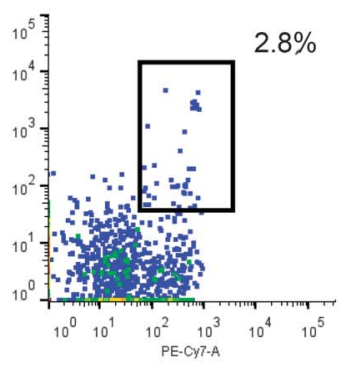

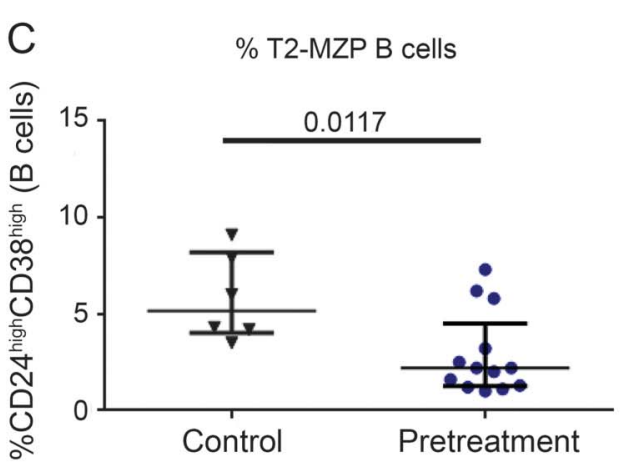

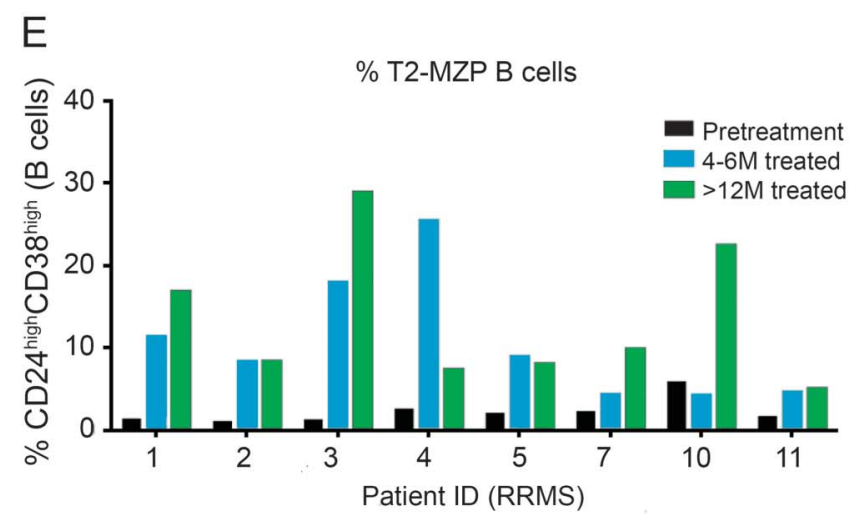

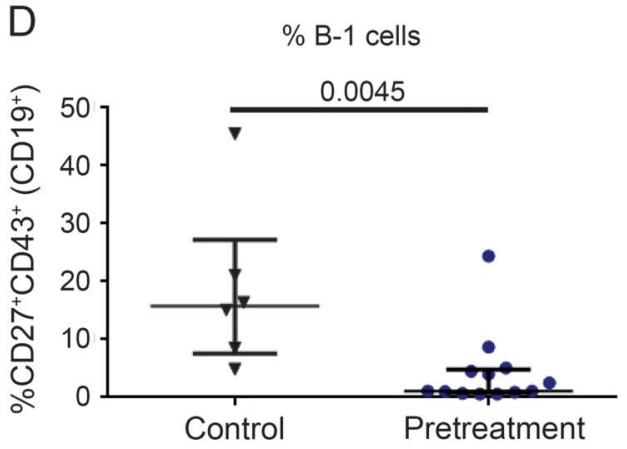

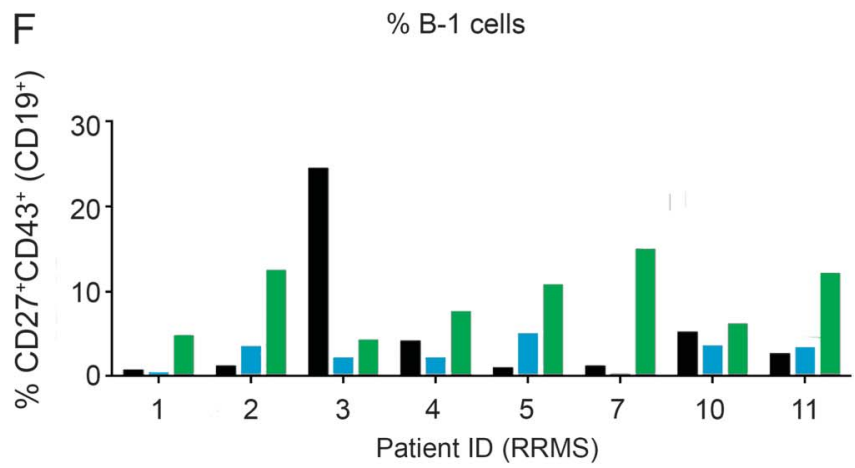

Peripheral blood mononuclear cells (PBMC) isolated from healthy controls and patients with relapsing-remitting multiple sclerosis (RRMS) before and after BG-12 treatment were stained and gated for CD19+ B cells as shown in figure 1 and then analyzed for coexpression of CD24 and CD38 or CD27 and CD43. (A) Representative staining from patient RRMS-8 shows the gating used to select the CD24 high CD38 high (T2-MZP) B-cell subset. (B) Representative staining from patient RRMS-8 shows gating used to analyze CD43+ CD27+ B-1 B cells before and after 4 months of BG-12 treatment. (C) Comparison of T2-MZP B cells in controls and patients with RRMS before treatment. Each dot represents an individual sample and lines are the median and interquartile range for each group. The $p$ values shown for group comparisons were calculated using Mann-Whitney tests. (D) Percentages of B-1 B cells in controls and patients with RRMS before treatment. Each dot represents an individual and lines are the median and interquartile range for each group. Exact $p$ value was calculated using Mann-Whitney test. (E) Percentages of T2-MZP B cells in individual patients with RRMS before BG-12 therapy and after 4-6 months and $>12$ months of treatment. (F) Longitudinal changes in percentage of B-1 B cells for individual patients with RRMS at baseline, 4-6 months, and $>12$ months BG-12 treatment.

Not all T2-MZP or B-1 B cells produce IL-10 after stimulation, and patients with systemic lupus erythematosus had T2-MZP B cells that were defective in IL-10 production. ${ }^{21}$ To determine whether B cells from the patients with RRMS were functional, CD19+ B cells were purified using magnetic bead positive selection, and then cultured with a CD 40 ligand-transduced cell line. ${ }^{20}$ This assay was dependent on having enough purified B cells, which was not achieved for all patients and time points. Figure 3A shows IL-10 data for the 3 patients with RRMS in this study who were analyzed at both the pretreatment and 4-6 months of BG-12 treatment time points. The percentages of T2-MZP and B-1 $\mathrm{B}$ cells in the sample prior to culture are shown in figure 3B. The results indicated that levels of IL-10 
Figure 3 B cells from most patients with relapsing-remitting multiple sclerosis (RRMS) produced interleukin-10 (IL-10) at levels that correlated with the presence of transitional 2 marginal zone precursor (T2-MZP) and B-1 B cells
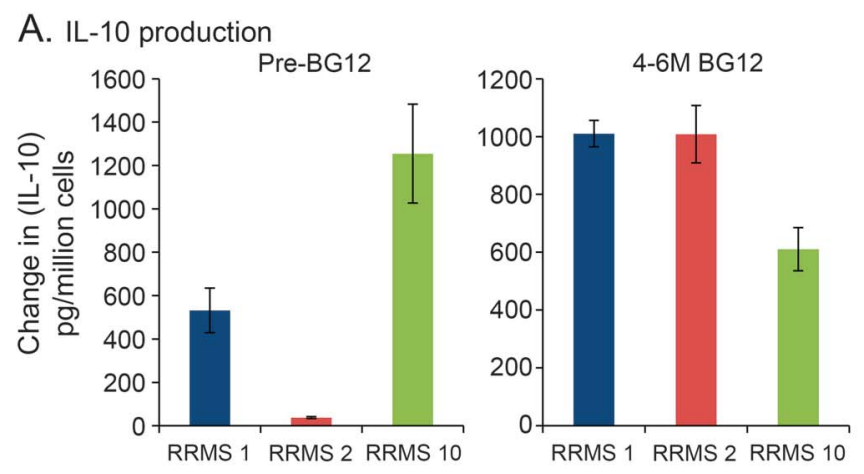

B. Regulatory B cells
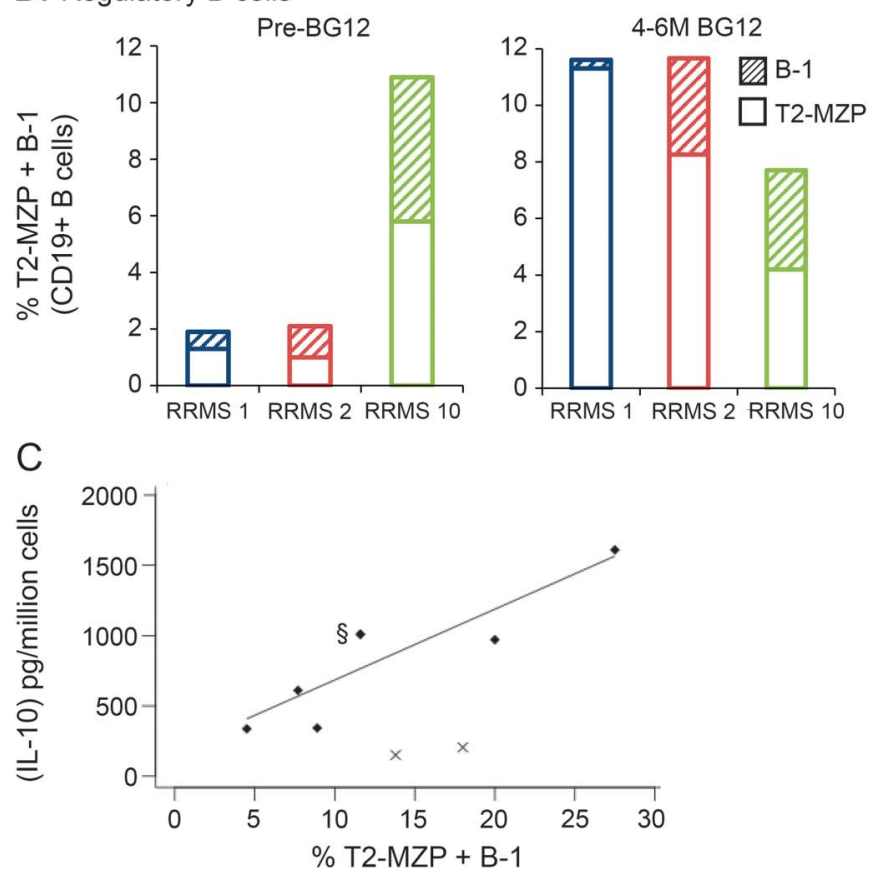

CD19+ B cells were positively selected by magnetic bead separation before and after 4-6 months of BG-12 treatment. Purified B cells were stimulated with irradiated hCD4OL-Fb for 6 days prior to measurement of $\mathrm{IL}-10$ in culture supernatants. Cultures containing hCD4OL$\mathrm{Fb}$ alone or $\mathrm{B}$ cells with $\mathrm{CD} 40 \mathrm{~L}^{\text {neg }}$ fibroblasts did not produce IL-10 (data not shown). (A) Mean IL-10 production \pm SD in triplicate culture wells. Student $t$ test calculated $* p$ values for the data before and after treatment were $p=0.0018, p<0.0001$, and $p=0.2084$ for patients RRMS-1, RRMS-2, and RRMS-10, respectively. (B) Stacked bar graph of percentage of circulating T2-MZP B cells (open bars) and B-1 B cells (hashed bars) within the total CD19+ B-cell population before culture. (C) Comparison of B-cell IL-10 production vs combined levels of T2-MZP and B-1 B cells after 4-6 months treatment for 9 patients. Two patients did not produce IL-10 despite high levels of regulatory B cells (marked with $\mathrm{x}$ ). Linear regression for the other 7 patients (diamonds) showed a high degree of correlation: $Y=$ $50.3 \mathrm{X}+181, R^{2}=0.79, F=18.7, p=0.0075$. $\S$ Data point at $11.6 \% \mathrm{~T} 2-\mathrm{MZP}+\mathrm{B}-1 \mathrm{~B}$ cells represents 2 patients, RRMS-1 and RRMS-2, who produced IL-10 =1,010 \pm 45 and 1,008 $\pm 99 \mathrm{pg} / \mathrm{million}$ cells, respectively.

produced by these 3 patients were comparable to the combined levels of T2-MZP and B-1 B cells before or after treatment, but not well-correlated with the individual subsets. A total of 9 patients with RRMS were analyzed for CD40 ligand-induced IL-10 production at the 4-6 months treatment time point (figure 3C).
While 7 of the 9 patients with RRMS released levels of IL-10 that correlated strongly with the percentage of T2-MZP plus B-1 B cells found in their blood, 2 patients with RRMS appeared to have a reduction in the expected levels of B-cell IL-10 production in this assay.

DISCUSSION Our data confirm that treatment of patients with RRMS with BG-12 leads to reductions in circulating lymphocytes, including B cells, as previously reported. ${ }^{12,18}$ Treatment with BG-12 was found to variably lower the total number of $\mathrm{CD} 27+$ memory $\mathrm{B}$ cells, as well as the $\mathrm{CD} 27^{\text {neg }}$ immature, transitional, and naive $\mathrm{B}$-cell subsets. In contrast, $\mathrm{CD} 24^{\text {high }} \mathrm{CD} 38^{\text {high }}$ T2-MZP B cells increased in percentage after 4-6 months of treatment and remained higher in number than baseline in $8 / 8(100 \%)$ patients after 1 year of treatment. Long-term treatment also led to increased numbers of circulating $\mathrm{CD} 43+\mathrm{CD} 27+$ B-1 cells. Both T2-MZP and B-1 B cells have been independently shown to produce the immune regulatory cytokine, IL-10, and the production of IL-10 by B cells in this study correlated with the combined presence of both of these cell subsets in 7/9 (78\%) patients, while 2 patients failed to produce IL-10 despite relatively high levels of T2MZP and B-1 cells. Thus, BG-12 treatment of patients with RRMS appeared to favor B cells that had immune regulatory potential.

The mechanisms underlying these differential effects of BG-12 on circulating B-lymphocyte subsets have not yet been determined. Some possibilities for the reductions in the majority of $\mathrm{B}$ cells include direct induction of apoptosis or indirect killing of $\mathrm{B}$ cells by other cells. ${ }^{15,24}$ Another possibility is that BG-12 may have initially affected $T_{H}$ cell viability or activation resulting in losses or changes to T-cell help that altered B-cell viability. ${ }^{25,26}$ Shifts in cytokine production from $T_{H} 1$ toward $T_{H} 2$ patterns have been noted in human $\mathrm{T}$ cells from patients treated with DMF. ${ }^{25}$ These changes in T-cell cytokine output may have contributed to the increase in regulatory B-cell subsets, since the $\mathrm{T}_{\mathrm{H}} 2$ cytokine IL- 5 has been shown to preferentially stimulate growth of immune regulatory mouse B-1 B cells that expressed Fas ligand and IL$10 .{ }^{27}$ Further work is necessary to understand the cells and processes involved and their relative importance to the therapeutic effects of BG-12.

Direct effects of BG-12 or DMF on signal transduction in human $B$ cells have not been previously reported. BG-12 is known to activate the nuclear factor (erythroid-derived 2)-like 2 (Nrf2) pathway in neuronal cells..$^{28}$ Unlike the proapoptotic effects of DMF on $\mathrm{T}$ cells, our group recently demonstrated that activation of the Nrf2 pathway by DMF can inhibit 
neuronal cell apoptosis as a possible mechanism of neuroprotection. ${ }^{7}$ It will be of interest to determine whether BG-12 activates different signaling pathways and has a pro vs antiapoptotic effect on different subsets of human B cells. One product of Nrf2 activation that may play a direct role in the immune response is heme oxygenase- 1 (HO-1), which is known to stimulate the functions of Treg cells. ${ }^{29-31}$ In contrast, very little is known about the role of $\mathrm{Nrf} 2$ and $\mathrm{HO}-1$ in regulatory $\mathrm{B}$-cell activation and function. It remains to be determined whether BG-12 has direct effects on proliferation or protection from apoptosis of T2-MZP or B-1 B cells. Other possibilities for the observed increases in these cell populations include indirect effects through activation of other cell populations or homeostatic proliferation response resulting from the loss of other lymphocytes.

In humans, CD24 $4^{\text {high }} \mathrm{CD} 38^{\text {high }}$ T2-MZP and $\mathrm{CD} 27+\mathrm{CD} 43+\mathrm{B}-1 \mathrm{~B}$ cells have been designated as regulatory $\mathrm{B}$-cell subsets based on their ability to produce IL-10. ${ }^{21,32}$ It should be noted that within these populations, IL-10 production only occurs in a fraction of the total subset and is dependent on the method of stimulation. ${ }^{21,23,32}$ Both the T2-MZP and B-1 B-cell subsets were increased in total cell number and percentage following long-term treatment in the majority of the patients we studied. The T2MZP B cells responded earlier and more consistently than the B-1 B cells, suggesting that different mechanisms were involved in their proliferation. Increases in T2-MZP B cells have been noted following treatment of patients with RRMS with other medications, suggesting that these cells may be highly important in the regulation of multiple sclerosis (MS) pathogenesis. ${ }^{33,34}$

The response among B-1 B cells in BG-12treated patients with RRMS was more complicated and individualized, with the increase in B-1 B cells only detected after 1 year of treatment, and only in 6 of the 8 patients analyzed. This may have been due in part to the fact that the majority of these innate $\mathrm{B}$ cells are resident in the lining of the gut and lungs, and the delayed increase in their numbers in the blood may reflect earlier activation or proliferation in the mucosa. Most of the patients had significantly lower levels of B-1 B cells prior to treatment, in agreement with findings of other investigators. ${ }^{35}$ However, the previous authors concluded that treatment of patients with RRMS with glatiramer acetate, interferon- $\beta$, or natalizumab had no effect on CD $43+$ CD27 + B-1 B cells. ${ }^{35}$ This was in sharp contrast to the effects of glatiramer acetate treatment in mouse EAE, which resulted in expansion and increased regulatory function of $\mathrm{CD} 5+\mathrm{B}-1 \mathrm{a}$ cells. ${ }^{36,37}$ It should be noted that CD5 is not a specific marker for B-1 cells in humans, complicating the interpretation of previous reports linking human CD5 + B cells to MS pathogenesis. ${ }^{22,38,39}$

We did not assess IL-10 production by intracellular staining, and therefore, were not able to determine whether the freshly isolated $\mathrm{B}$ cells were expressing IL-10 in vivo. The levels of IL-10 produced by 7 out of 9 of the patients with RRMS correlated with the combined percentages of T2-MZP and B-1 B cells in the sample, but not with either of the subsets independently. The data for these 7 patients contrasted with previous reports associating autoimmunity with poorly functioning regulatory $\mathrm{B}$ cells, and suggest that $B$ cells in these patients with RRMS would be capable of contributing to immune regulation. Notably, B cells from 2 of the patients with RRMS in our study did not produce significant amounts of IL-10 despite having relatively high levels of T2MZP and B-1 B cells. It will be interesting to track clinical responses in these patients long term, and to perform similar analyses on a larger population to determine whether the beneficial effects of BG-12 correlate with the activation and competence of regulatory B cells.

It should be noted that this study was done with a limited number of patients, and that continued work should be done with larger groups and longer followup to confirm these findings. Study of more complex variables, such as the effects of prior treatments as well as duration and severity of disease at treatment initiation, will require much larger groups and may be important in determining which patients are most likely to benefit from BG-12 therapy. An important aspect of our study is the variability of the responses of B cells to BG-12 treatment and how this may relate to clinical responses. None of these 13 patients has relapsed and there have been no new MRI lesions during this study (data not shown). The patients have tolerated BG-12 treatment well with only a few reports of minor side effects that have subsided over time. With several cases of PML having been reported, there is understandable concern about longterm effects of BG-12 and a need to screen for JC virus. $^{8-10}$ None of the patients in our study have had signs of active JC virus. These issues highlight the need for more long-term studies with large cohorts of patients, which may lead to a better understanding of variables that relate not only to favorable outcomes, but also to severe negative side effects such as PML. It will be interesting to determine whether the short-term effects of BG-12 on T2-MZP or B-1 $\mathrm{B}$ cells will predict the long-term clinical efficacy of BG-12 treatment.

\section{STUDY FUNDING}

No commercial funding was received to support this work. The study was funded with institutional support from the University of Michigan Medical School. 


\section{DISCLOSURE}

S.K. Lundy received nonprofit honorarium from University of Connecticut, is on the editorial board for The Open Rheumatology Journal, and received research support from Merck, Chugai, NIH, University of Michigan Medical School, and Edward T. and Ellen K. Dryer Foundation. Q. Wu and Q. Wang report no disclosures. C.A. Dowling received travel funding form Chugai Pharmaceuticals. S.H. Taitano and G. Mao report no disclosures. Y. Mao-Draayer served on the scientific advisory board for, received travel funding, and/or speaker honoraria from, and consulted for Acorda, Bayer, Biogen Idec, EMD Serono, Genzyme, Novartis, Questor, Chugai, and Teva, and received research support from NIH NIAID and NINDS. Go to Neurology.org/nn for full disclosure forms.

Received September 25, 2015. Accepted in final form December 22, 2015.

\section{REFERENCES}

1. Kim W, Zandona ME, Kim SH, Kim HJ. Oral diseasemodifying therapies for multiple sclerosis. J Clin Neurol 2015;11:9-19.

2. Cross AH, Naismith RT. Established and novel diseasemodifying treatments in multiple sclerosis. J Intern Med 2014;275:350-363.

3. Gold R, Kappos L, Arnold DL, et al. Placebo-controlled phase 3 study of oral BG-12 for relapsing multiple sclerosis. N Engl J Med 2012;367:1098-1107.

4. Fox RJ, Miller DH, Phillips JT, et al. Placebo-controlled phase 3 study of oral BG-12 or glatiramer in multiple sclerosis. N Engl J Med 2012;367:1087-1097.

5. Sheremata W, Brown AD, Rammohan KW. Dimethyl fumarate for treating relapsing multiple sclerosis. Expert Opin Drug Saf 2015;14:161-170.

6. Dubey D, Kieseier BC, Hartung HP, et al. Dimethyl fumarate in relapsing-remitting multiple sclerosis: rationale, mechanisms of action, pharmacokinetics, efficacy and safety. Expert Rev Neurother 2015;15:339-346.

7. Wang Q, Chuikov S, Taitano S, et al. Dimethyl fumarate protects neural stem/progenitor cells and neurons from oxidative damage through Nrf2-ERK1/2 MAPK pathway. Int J Mol Sci 2015;16:13885-13907.

8. Rosenkranz T, Novas M, Terborg C. PML in a patient with lymphocytopenia treated with dimethyl fumarate. $\mathrm{N}$ Engl J Med 2015;372:1476-1478.

9. Nieuwkamp DJ, Murk JL, van Oosten BW, et al. PML in a patient without severe lymphocytopenia receiving dimethyl fumarate. N Engl J Med 2015;372:14741476.

10. Bartsch T, Rempe T, Wrede A, et al. Progressive neurologic dysfunction in a psoriasis patient treated with dimethyl fumarate. Ann Neurol 2015;78:501-514.

11. Spencer CM, Crabtree-Hartman EC, Lehmann-Horn K, Cree BA, Zamvil SS. Reduction of CD8(+) T lymphocytes in multiple sclerosis patients treated with dimethyl fumarate. Neurol Neuroimmunol Neuroinflamm 2015 2:e76. doi: 10.1212/NXI.0000000000000076.

12. Berkovich R, Weiner LP. Effects of dimethyl fumarate on lymphocyte subsets. Mult Scler Relat Disord 2015;4: 339-341.

13. Ockenfels HM, Schultewolter T, Ockenfels G, Funk R Goos M. The antipsoriatic agent dimethylfumarate immunomodulates $\mathrm{T}$-cell cytokine secretion and inhibits cytokines of the psoriatic cytokine network. Br J Dermatol 1998;139:390-395.

14. Schilling S, Goelz S, Linker R, Luehder F, Gold R. Fumaric acid esters are effective in chronic experimental autoimmune encephalomyelitis and suppress macrophage infiltration. Clin Exp Immunol 2006;145:101-107.

15. Treumer F, Zhu K, Glaser R, Mrowietz U. Dimethylfumarate is a potent inducer of apoptosis in human $\mathrm{T}$ cells. J Invest Dermatol 2003;121:1383-1388.

16. Mann MK, Maresz K, Shriver LP, Tan Y, Dittel BN. $\mathrm{B}$ cell regulation of $\mathrm{CD} 4+\mathrm{CD} 25+\mathrm{T}$ regulatory cells and IL-10 via B7 is essential for recovery from experimental autoimmune encephalomyelitis. J Immunol 2007;178: 3447-3456.

17. Matsushita T, Horikawa M, Iwata Y, Tedder TF. Regulatory B cells (B10 cells) and regulatory $\mathrm{T}$ cells have independent roles in controlling experimental autoimmune encephalomyelitis initiation and late-phase immunopathogenesis. J Immunol 2010;185:2240-2252.

18. Schimrigk $S$, Brune N, Hellwig $K$, et al. Oral fumaric acid esters for the treatment of active multiple sclerosis: an open-label, baseline-controlled pilot study. Eur J Neurol 2006;13:604-610.

19. Sanz I, Wei C, Lee FE, Anolik J. Phenotypic and functional heterogeneity of human memory B cells. Semin Immunol 2008;20:67-82.

20. Blair PA, Chavez-Rueda KA, Evans JG, et al. Selective targeting of B cells with agonistic anti-CD40 is an efficacious strategy for the generation of induced regulatory T2like B cells and for the suppression of lupus in MRL/lpr mice. J Immunol 2009;182:3492-3502.

21. Blair PA, Norena LY, Flores-Borja F, et al. CD19(+) CD24(hi)CD38(hi) B cells exhibit regulatory capacity in healthy individuals but are functionally impaired in systemic Lupus Erythematosus patients. Immunity 2010;32: 129-140.

22. Griffin DO, Holodick NE, Rothstein TL. Human B1 cells in umbilical cord and adult peripheral blood express the novel phenotype CD20+CD27+ CD43+ CD70. J Exp Med 2011;208:67-80.

23. Iwata $Y$, Matsushita $T$, Horikawa $M$, et al. Characterization of a rare IL-10-competent B-cell subset in humans that parallels mouse regulatory B10 cells. Blood 2011;117: 530-541.

24. Tsubaki M, Ogawa N, Takeda T, et al. Dimethyl fumarate induces apoptosis of hematopoietic tumor cells via inhibition of NF-kappaB nuclear translocation and downregulation of $\mathrm{Bcl}-\mathrm{xL}$ and XIAP. Biomed Pharmacother 2014;68:999-1005.

25. Moed H, Stoof TJ, Boorsma DM, et al. Identification of anti-inflammatory drugs according to their capacity to suppress type- 1 and type- $2 \mathrm{~T}$ cell profiles. Clin Exp Allergy 2004;34:1868-1875.

26. de Jong R, Bezemer AC, Zomerdijk TP, van de PouwKraan T, Ottenhoff TH, Nibbering PH. Selective stimulation of $\mathrm{T}$ helper 2 cytokine responses by the antipsoriasis agent monomethylfumarate. Eur J Immunol 1996;26:2067-2074.

27. Klinker MW, Reed TJ, Fox DA, Lundy SK. Interleukin-5 supports the expansion of fas ligand-expressing killer B cells that induce antigen-specific apoptosis of CD4(+) T cells and secrete interleukin-10. PLoS One 2013;8: e70131.

28. Scannevin RH, Chollate S, Jung MY, et al. Fumarates promote cytoprotection of central nervous system cells against oxidative stress via the nuclear factor (erythroidderived 2)-like 2 pathway. J Pharmacol Exp Ther 2012; 341:274-284. 
29. Sun L, Shi T, Qiao H, et al. Hepatic overexpression of heme oxygenase-1 improves liver allograft survival by expanding $\mathrm{T}$ regulatory cells. J Surg Res 2011;166:e187-194.

30. George JF, Braun A, Brusko TM, et al. Suppression by $\mathrm{CD} 4+\mathrm{CD} 25+$ regulatory $\mathrm{T}$ cells is dependent on expression of heme oxygenase- 1 in antigen-presenting cells. Am J Pathol 2008;173:154-160.

31. Lin SX, Lisi L, Dello Russo C, et al. The antiinflammatory effects of dimethyl fumarate in astrocytes involve glutathione and heme oxygenase-1. ASN Neuro 2011;3:e00055.

32. Griffin DO, Rothstein TL. Human “orchestrator” CD11b (+) B1 cells spontaneously secrete interleukin-10 and regulate T-cell activity. Mol Med 2012;18:1003-1008.

33. Schubert RD, Hu Y, Kumar G, et al. IFN-beta treatment requires $\mathrm{B}$ cells for efficacy in neuroautoimmunity. J Immunol 2015;194:2110-2116.

34. Grutzke B, Hucke S, Gross CC, et al. Fingolimod treatment promotes regulatory phenotype and function of $B$ cells. Ann Clin Transl Neurol 2015;2:119-130.
35. Rovituso D, Heller S, Schroeter M, Kleinschnitz C, Kuerten S. B1 cells are unaffected by immune modulatory treatment in remitting-relapsing multiple sclerosis patients. J Neuroimmunol 2014;272:86-90.

36. Begum-Haque S, Christy M, Ochoa-Reparaz J, et al. Augmentation of regulatory B cell activity in experimental allergic encephalomyelitis by glatiramer acetate. J Neuroimmunol 2011;232:136-144.

37. Begum-Haque S, Sharma A, Christy $M$, et al. Increased expression of $\mathrm{B}$ cell-associated regulatory cytokines by glatiramer acetate in mice with experimental autoimmune encephalomyelitis. J Neuroimmunol 2010;219:47-53.

38. Villar LM, Espino M, Roldan E, et al. Increased peripheral blood CD5 + B cells predict earlier conversion to MS in high-risk clinically isolated syndromes. Mult Scler 2011; 17:690-694.

39. Seidi OA, Semra YK, Sharief MK. Expression of CD5 on B lymphocytes correlates with disease activity in patients with multiple sclerosis. J Neuroimmunol 2002;133:205-210. 


\title{
Neurology \\ Neuroimmunology \& Neuroinflammation
}

\author{
Dimethyl fumarate treatment of relapsing-remitting multiple sclerosis influences B-cell \\ subsets \\ Steven K. Lundy, Qi Wu, Qin Wang, et al. \\ Neurol Neuroimmunol Neuroinflamm 2016;3; \\ DOI 10.1212/NXI.0000000000000211
}

This information is current as of March 3, 2016

\section{Updated Information \& \\ Services}

References

Citations

Subspecialty Collections

Permissions \& Licensing

Reprints including high resolution figures, can be found at:

http://nn.neurology.org/content/3/2/e211.full.html

This article cites 39 articles, 7 of which you can access for free at: http://nn.neurology.org/content/3/2/e211.full.html\#\#ref-list-1

This article has been cited by 2 HighWire-hosted articles: http://nn.neurology.org/content/3/2/e211.full.html\#\#otherarticles

This article, along with others on similar topics, appears in the following collection(s):

Autoimmune diseases

http://nn.neurology.org//cgi/collection/autoimmune_diseases Multiple sclerosis

http://nn.neurology.org//cgi/collection/multiple_sclerosis

Information about reproducing this article in parts (figures,tables) or in its entirety can be found online at:

http://nn.neurology.org/misc/about.xhtml\#permissions

Information about ordering reprints can be found online:

http://nn.neurology.org/misc/addir.xhtml\#reprintsus

Neurol Neuroimmunol Neuroinflamm is an official journal of the American Academy of Neurology.

Published since April 2014, it is an open-access, online-only, continuous publication journal. Copyright $\odot$ 2016 American Academy of Neurology. All rights reserved. Online ISSN: 2332-7812.

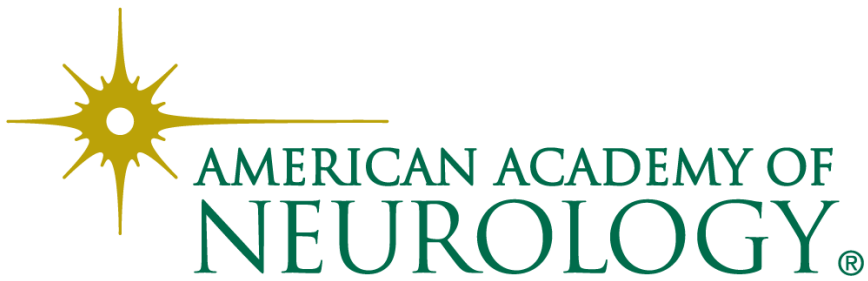

